\title{
Comparative radiological and morphological study of human pancreas. Pancreatitis like changes in postmortem ductograms and their morphological pattern. Possible implication for ERCP
}

\author{
P SCHMITZ-MOORMANN, G W HIMMELMANN, J-W BRANDES, U R FÖLSCH \\ H LORENZ-MEYER, H MALCHOW, L N SOEHENDRA, AND M WIENBECK
}

\begin{abstract}
From the Departments of Pathology, and Medical-Biological Statistics and Documentation of the Philipps-University of Marburg, the Departments of Internal Medicine of the Universities of Marburg, Göttingen, Düsseldorf, Tübingen, the Department of Surgery of the University of Hamburg, and the Municipal Clinic of Braunschweig, FRG
\end{abstract}

SUMMARY A postmortem study by ductography and histology was performed on 69 human pancreata with no clinical or histological signs of chronic pancreatitis. The ductograms, supplemented by five postmortem ductograms of chronic pancreatitis, were independently evaluated by six clinicians, skilled in ERCP; the degree of alteration was estimated by simple rating, forced choice rating, and by determination of the grade of chronic pancreatitis, Histologically, the amount of intraductal epithelial proliferation, periductal, intralobular and perilobular fibrosis, intraductal protein plugs, and fat necrosis was determined by semiquantitative methods. The six ductographical evaluations significantly differed in the level of their data, but corresponded in the range of distribution. All evaluations were correct regarding judgement of ductograms from patients with chronic pancreatitis. Ductograms of patients without chronic pancreatitis, however, were also frequently classified as chronic pancreatitis; overall $81 \%$ (minimal $37 \%$, moderate $33 \%$, severe $11 \%$ ). This high level of false positive diagnosis indicates the frequency of pancreatitis like lesions in the main duct and its side branches in patients without chronic pancreatitis. Ductal lesions were significantly correlated with perilobular fibrosis. This finding favours the assumption, that in the non-inflamed pancreas, perilobular fibrosis plays a key-role in the development of ductal alterations, as in chronic pancreatitis. Perilobular fibrosis may result from intralobular inflammation caused by agedependent intraductal epithelial hyperplasia.

Since the first successful endoscopic retrograde pancreatography (ERCP) in 1968, ${ }^{1}$ ERCP has become a routine method in the diagnosis of chronic pancreatitis. The ductal alterations, decisive in the diagnosis of chronic pancreatitis, are well known and generally correlate with the clinical and laboratory parameters of chronic pancreatitis. ${ }^{2-5}$ Alterations of the pancreatic duct systems are also produced by age-dependent changes ${ }^{6-9}$ and may ductographically mimic chronic pancreatitis. The

Address for correspondence: Prof Dr P Schmitz-Moormann, Medizinisches Zentrum für Pathologie, Robert Koch-Straße 5, D-3550 Marburg. FRG

Received for publication 15 June 1984 differentation between these 'physiological' alterations of the pancreatic duct systems and minimal or mild forms of chronic pancreatitis is not yet clear. Moreover, no data are available regarding the relationship between ductograms and histology in age-dependent pancreatic lesions. The material of our comparative radiological and morphological studies of the human pancreas, ${ }^{6-9}$ enabled us to study the following topics: (1) the specifity of the criteria of ERCP in differentiating between pancreata with and without chronic inflammation, and (2) the relationships between ductographical and histological lesions in age-dependent pancreatic alterations. 


\section{Methods}

\section{MATERIALS}

The postmortem study was performed on 75 human pancreata removed within 10 hours of death. Five patients suffered from chronic pancreatitis (ages 33, $40,48,75,79$ years; two men, three women; alcoholic three). Seventy patients showed no signs of chronic pancreatitis, neither macroscopically nor microscopically, but only age-dependent alterations, which are clearly distinguishable from chronic pancreatitis. Moreover, no signs of chronic pancreatitis were known from the clinical history. One of these cases was omitted because of incomplete histological data. Twenty nine patients presented bile diseases on necropsy, mostly gallstones. Cirrhosis was seen in one patient, gastric ulcers in four patients and duodenal ulcers in two patients.

After necropsy, a tubule was fixed in the papilla and the pancreatic duct system was filled with a contrast medium, using a pressure of $20 \mathrm{~cm} \mathrm{H}_{2} \mathrm{O}$. The contrast medium was a mixture of $40 \%$ bovine albumin solution (25\%) and $60 \%$ Micropaque ${ }^{\circledR}$. The pancreas was fixed in $4 \%$ formalin, the adherent tissue removed and the isolated organ radiographed. The organs were cut into slices of $8 \mathrm{~mm}$ thickness, paraffin embedded, and were studied histologically in giant sections.

\section{EVALUATION OF THE DUCTOGRAMS (Fig. 1)}

The 75 ductograms were divided into five groups, each of 15 radiograms. The clinical observer had to evaluate each series independent of the other series and the other observers. Three evaluations were performed in each series: (1) simple rating, using a scale from 1-9; (2) forced choice rating - that is, the ductograms of each series were evaluated against a line where the slightest lesions were at one end and the most severe alterations were at the other end; (3) evaluation of the degree of chronic pancreatitis using a scale from $0-3$. The criteria of the evaluation was taken from Kasugai et al, ${ }^{3}$ estimating alterations of the main pancreatic duct and its branches.

\section{HISTOLOGICAL EVALUATION}

The histological evaluation covered the variables: proliferation of ductal epithelium, periductal fibrosis, intralobular fibrosis, perilobular fibrosis, intraductal protein plugs, and fat necrosis; ${ }^{6}$ (Figs. $2-4)$. The number of each lesion was determined in each slice, summed up for head body and tail, and divided by the number of the slices of each region. A mean value of $0<\bar{x} \leqslant 0.5$ was valued as grade 1 , a mean value of $0 \cdot 5<\bar{x} \leqslant 1$ as grade 2 , a mean value of $1 \leqslant \bar{x}$ as grade 3 . The values of head, body and tail were summed up, thus providing an overall value on a scale from $0-9$, with $0=$ no, $1-3=$ slight, $4-6=$ moderate and 7-9 = severe alterations.

\section{STATISTICAL EVALUATION}

Frequencies were computed for all variables, both for all patients and. for patients without chronic pancreatitis. The influence of age, sex, bile disease and gastroduodenal ulcers on ductograms, and histology was determined by correlation analyses. The statistical comparison between ductography and histology was done with the mean values of each case in the six simple rating evaluations. Moreover, the rating scale of ductographic changes was subdivided in $1<2 \cdot 5=$ normal, $2 \cdot 5<4 \cdot 0=$ borderline and $4 \cdot 0-9 \cdot 0=$ abnormal.

\section{Results}

Evaluation of simple rating of ductograms showed significant differences between some observers (Table 1). A z-transformation, however, revealed that the six observers agreed in the range of their evaluation and were different by the levels only. Similarly, significant differences were seen in the grading of pancreatitis (Table 2). The diagnosis of all observers was correct in their judgment of chronic pancreatitis. Ductograms of patients without chronic pancreatitis were also often classified as chronic pancreatitis (Table 3). Forty two per cent of these ductograms were falsely estimated by all observers. Only one ductogram, was classed as normal by all observers. An overall calculation of the six evaluations revealed the diagnosis of a normal pancreas in 19\% only (Table 2). Even the clinician, mostly skilled in ERCP (no. 4) who had evaluated more than $18000 \mathrm{ERCP}$, gave false positive results in $42 \%$.

Histologically, most often perilobular fibrosis and ductal epthelial hyperplasia were present, followed by intralobular and perilobular fibrosis (Table 4). Ductal epithelial hyperplasia was significantly correlated with intralobular and perilobular fibrosis as well as with fat necrosis, while perilobular fibrosis was also correlated with intralobular fibrosis, and fat necrosis (Table 4).

The relationships between ductographical and histological lesions are shown in Table 5. A significant correlation was present between ductographical changes and perilobular fibrosis. Significant age dependency existed in ductal epithelial hyperplasia $(p<0.01)$ and intralobular fibrosis $(p<0.05)$ as well as in ductographical changes $(p<0 \cdot 05)$. No significant correlation was found to bile tract diseases or gastroduodenal ulcers. 


\section{Biscussion}

Each multiple evaluation is complicated by inconsistent handling of the criteria of evaluation by the different observers. In our study, we hoped to overcome this problem by using the distinct criteria of Kasugai $e t \mathrm{al}^{3}$ in the estimation of the ductal alterations. Moreover, the six evaluators were
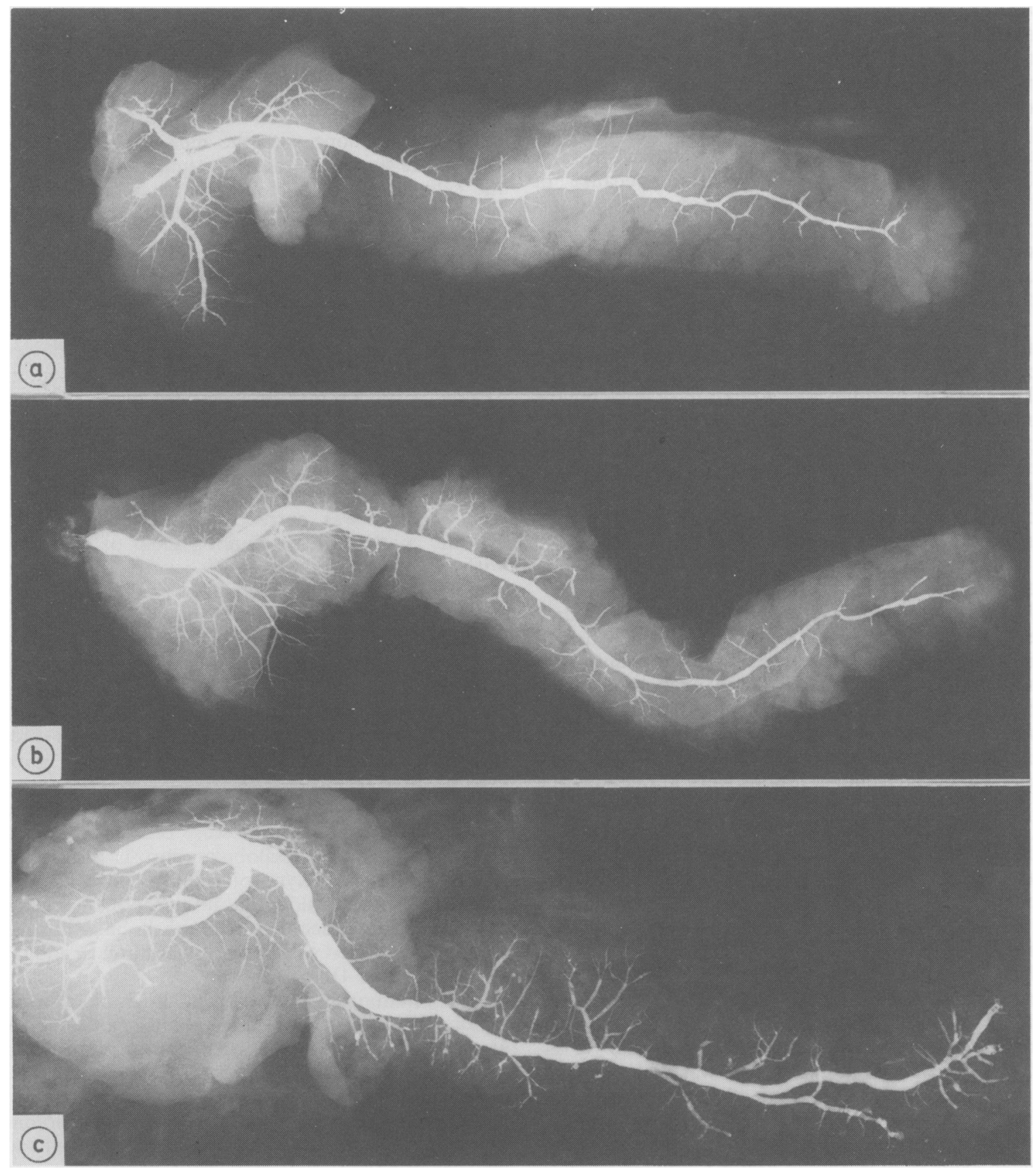

Fig. 1 Postmortem ductograms of human pancreas. (a-c) Organs with no histological signs of chronic pancreatitis. 


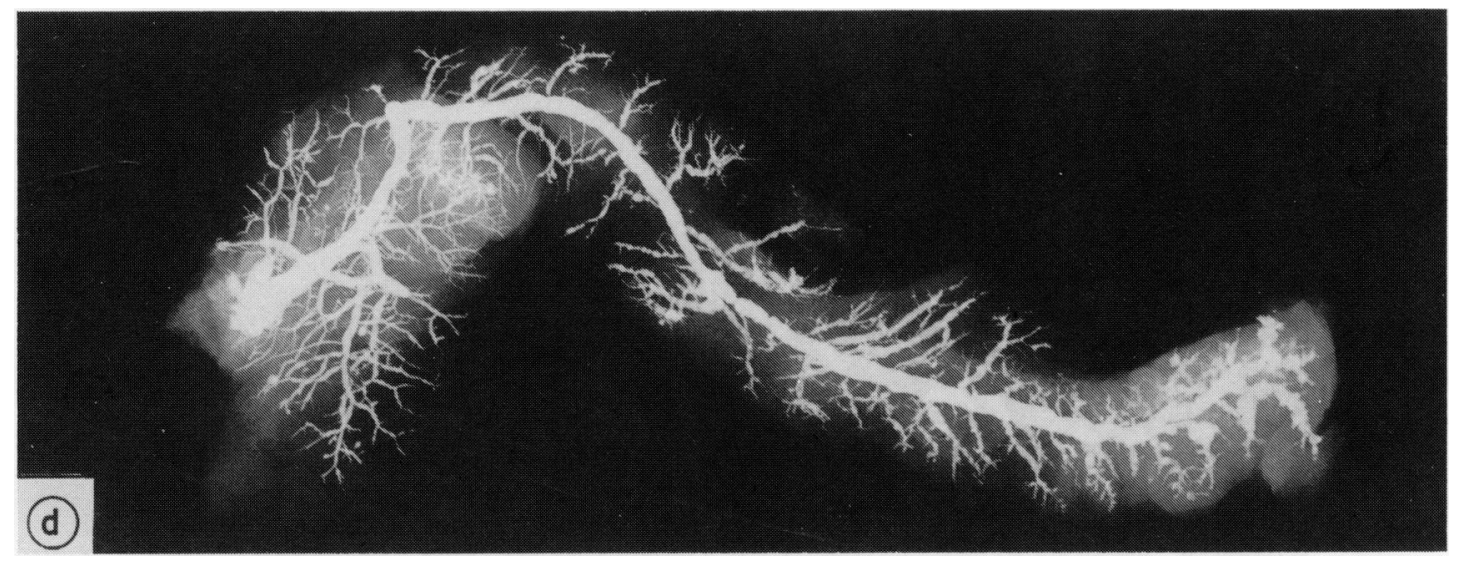

Fig. 1 (continued) (d) Organ with histologically proved chronic pancreatitis ( $\dot{H} P T)$

Results of the ductographical evaluations of these four pancreata

\begin{tabular}{clllllll}
\hline \multicolumn{7}{l}{} & \multicolumn{7}{l}{ Estimation of degree of chronic pancreatitis } \\
\cline { 2 - 9 } Age & Sex & $\begin{array}{l}\text { 1st } \\
\text { observer }\end{array}$ & $\begin{array}{l}\text { 2nd } \\
\text { observer }\end{array}$ & $\begin{array}{l}3 \text { 3rd } \\
\text { observer }\end{array}$ & $\begin{array}{l}\text { 4th } \\
\text { observer }\end{array}$ & $\begin{array}{l}\text { 5th } \\
\text { observer }\end{array}$ & $\begin{array}{l}\text { 6th } \\
\text { observer }\end{array}$ \\
\hline (a) 40 & Man & 0 & 0 & 2 & 0 & 2 & 2 \\
\hline (b) 72 & Man & 2 & 1 & 1 & 0 & 1 & 2 \\
\hline (c) 67 & Man & 2 & 2 & 2 & 1 & 2 & 2 \\
\hline (d) 35 & Woman & 3 & 3 & 3 & 2 & 2 & 3 \\
\hline
\end{tabular}

obliged to work scrutinously by using forced choice rating as an additional method of evaluation. Nevertheless, the six evaluations differed distinctly. Each evaluator, however, was very stable regarding the criteria, and there was good correlation in the range of the evaluation of the six observers. Thus, the results are comparable and consistent. Most of the ductograms of the histologically unaffected organs, however, were classified as chronic pancreatitis. Even the most skilled observer

Table 1 Evaluation of simple rating of 74 postmortem ductograms by six observers

\begin{tabular}{|c|c|c|c|c|c|c|}
\hline \multirow[b]{2}{*}{ Rating scale } & \multicolumn{6}{|l|}{ Observer } \\
\hline & No 1 (\%) & No $2(\%)$ & No $3(\%)$ & No $4(\%)$ & No $5(\%)$ & No $6(\%)$ \\
\hline 1 & $5 \cdot 3$ & $6 \cdot 7$ & $2 \cdot 7$ & $52 \cdot 0$ & $1 \cdot 3$ & $18 \cdot 7$ \\
\hline 2 & $13 \cdot 3$ & $9 \cdot 3$ & $10 \cdot 7$ & $24 \cdot 0$ & $12 \cdot 0$ & $12 \cdot 0$ \\
\hline 3 & $16 \cdot 0$ & $18 \cdot 7$ & $13 \cdot 3$ & $12 \cdot 0$ & $17 \cdot 3$ & $18 \cdot 7$ \\
\hline 4 & $26 \cdot 7$ & $25 \cdot 3$ & $25 \cdot 3$ & $1 \cdot 3$ & $12 \cdot 0$ & $12 \cdot 0$ \\
\hline 5 & $12 \cdot 0$ & $25 \cdot 3$ & 32.0 & $1 \cdot 3$ & $13 \cdot 3$ & $10 \cdot 7$ \\
\hline 6 & $12 \cdot 0$ & $5 \cdot 3$ & $6 \cdot 7$ & - & $14 \cdot 7$ & $10 \cdot 7$ \\
\hline 7 & 8.0 & $6 \cdot 7$ & $5 \cdot 3$ & $5 \cdot 3$ & $16 \cdot 0$ & 8.0 \\
\hline 8 & $6 \cdot 7$ & $2 \cdot 7$ & $4 \cdot 0$ & 4.0 & $12 \cdot 0$ & $5 \cdot 3$ \\
\hline 9 & - & - & - & - & 1.3 & 4.0 \\
\hline $\begin{array}{l}\overline{\mathbf{x}}+\mathrm{s} \text { of the } \\
\text { rating values }\end{array}$ & $4 \cdot 28 \pm 1 \cdot 88$ & $4 \cdot 09 \pm 1 \cdot 64$ & $4 \cdot 35 \pm 1 \cdot 56$ & $2 \cdot 17 \pm 1 \cdot 90$ & $5 \cdot 00 \pm 2 \cdot 06$ & $3 \cdot 99 \pm 2 \cdot 35$ \\
\hline
\end{tabular}

Observer no 4 significantly ( $\mathrm{p}<0.001$ ) reduced versus no 1, 2, 3, 5, 6 .

Observer no 5 significantly increased versus no $1,2,3(\mathrm{p}<0.05)$, no $6(\mathrm{p}<0.01)$ and no $4(\mathrm{p}<0.001)$. 


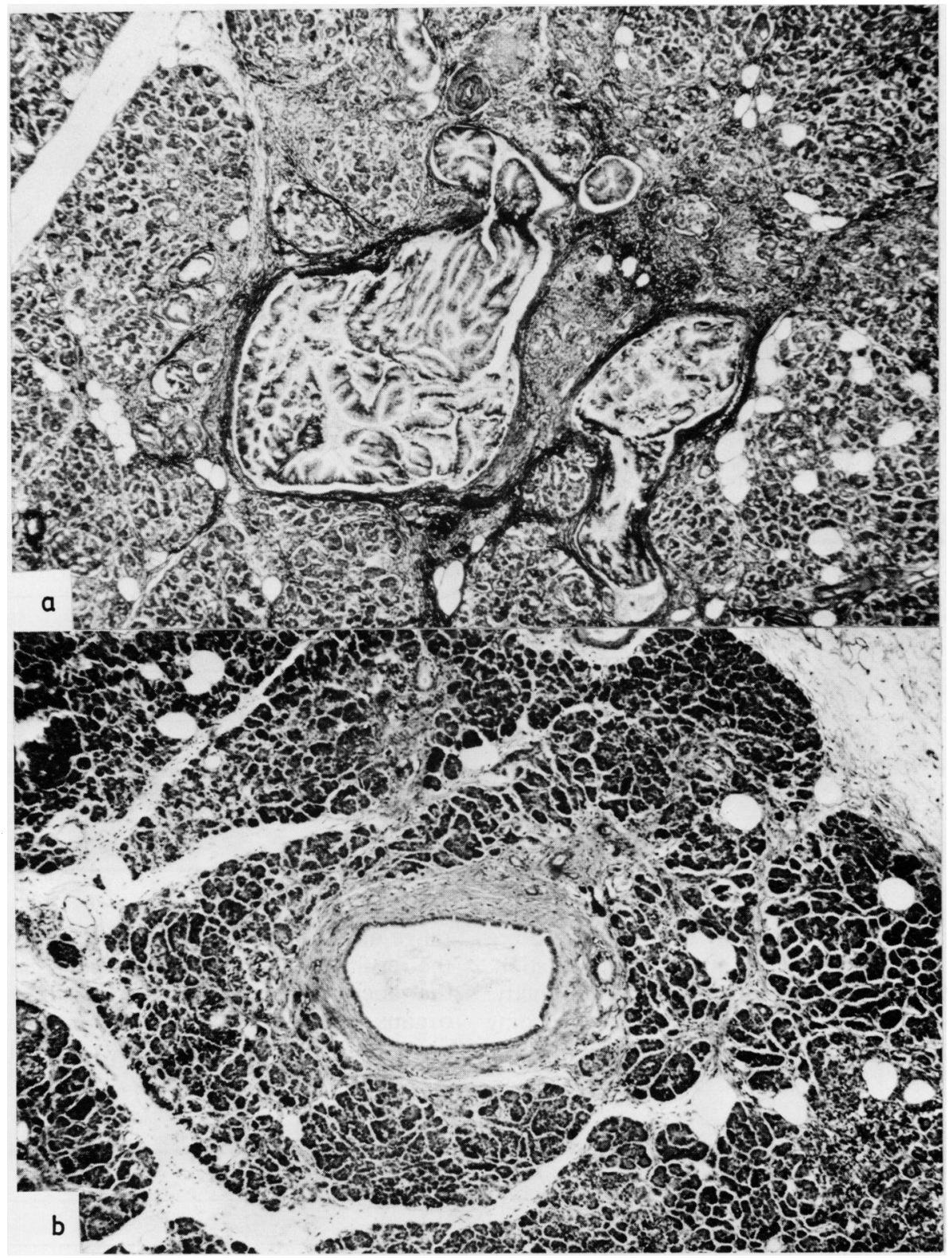

Fig. 2 Age-dependent alterations of the pancreas ( $H E, \times 33$ original magnification). (a) Intraductal epithelial proliferation and slight intralobular fibrosis. (b) Periductal fibrosis encroaching the adjacent parenchyma.

presented a false positive diagnosis in nearly $50 \%$. These results clearly elucidate that ductal abnormalities, identical with those of at least minimal chronic pancreatitis, are common in subjects without clinical and anatomical evidence of chronic pancreatitis.
A direct comparison of our ductograms with ERCP is impossible. On the one hand, the use of a contrasting medium, containing barium and the radiographing of the isolated organs result in pictures of extremely high contrast. On the other hand, our method allows an imaging of the smallest 


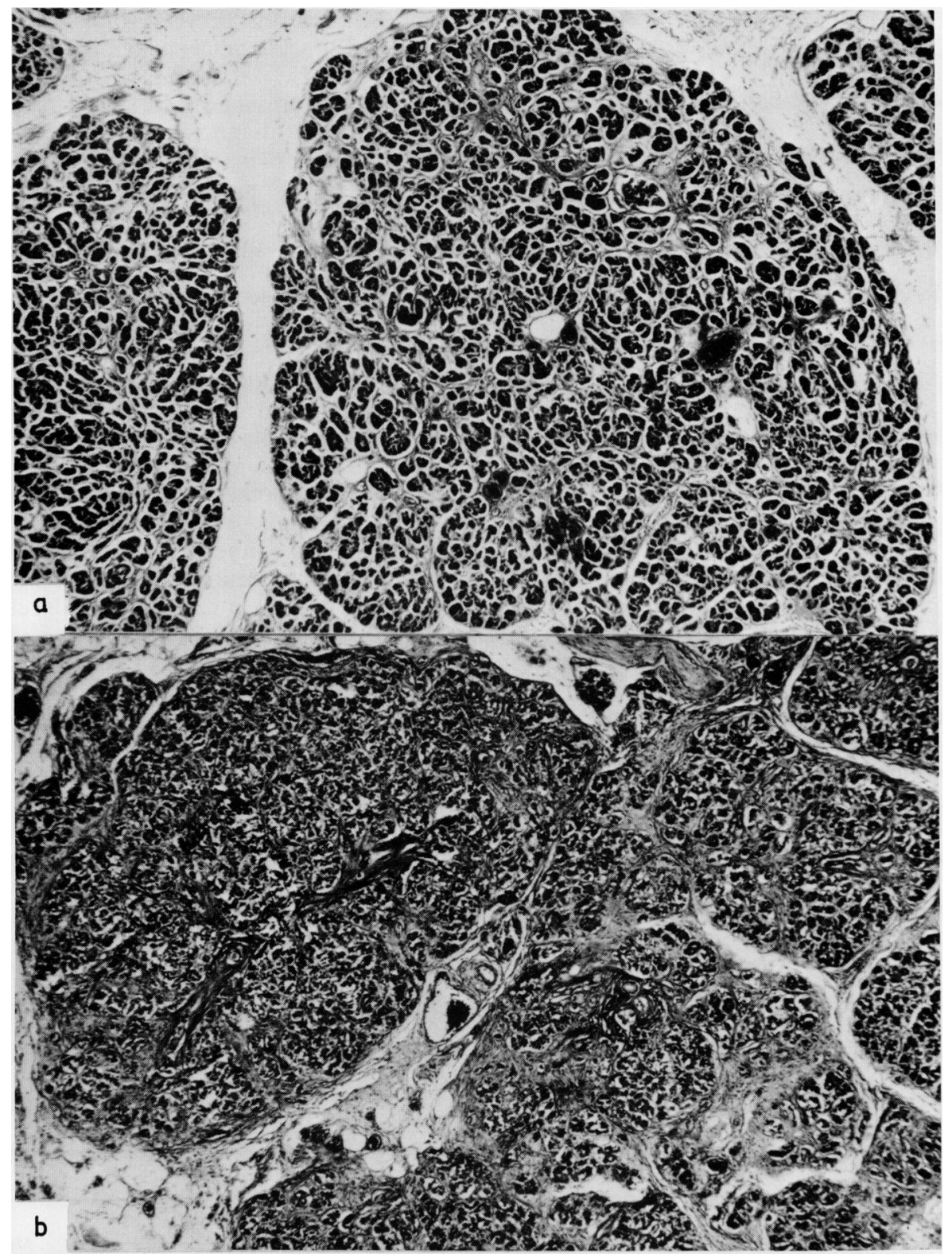

Fig. 3 Age-dependent alterations of the pancreas ( $H E, \times 33$ original magnification). (a) Mild intralobular fibrosis. (b) Marked intralobular fibrosis and moderate perilobular fibrosis.

side branches of the duct systems, which can be reached in ERCP only together with parenchymal opacification. Thus, a great deal of ductal alterations, especially of smaller side branches, may be detectable by postmortem ductograms only, and not by ERCP. But these ductal lesions are not artefacts. Therefore, paradoxically the diagnostic value of small duct alterations in ERCP may decrease with improving quality of the radiograph. This paradoxon is confirmed by the change of the criteria in the diagnosis of chronic pancreatitis during the last decade. In 1972 Kasugai et $a l^{3}$ 


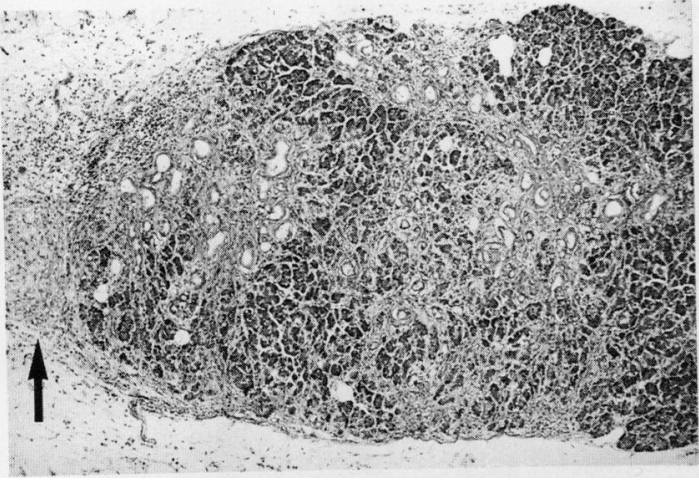

Fig. 4 Age-dependent alterations of the pancreas (HE, $\times 53$ original magnification). Marked intralobular fibrosis. Partly resorbed perilobular fat necrosis (arrow) with slight perilobular fibrosis.

diagnosed mild chronic pancreatitis, if alterations like irregular distribution, dilatation and stenosis were present anywhere in the side branches.

In 1983 the International Workshop on Classification of Pancreatitis in Cambridge ${ }^{10}$ recommends a diagnosis of chronic pancreatitis only, if more than three abnormal side branches are present. Perhaps in some years with further improvement of ERCP the diagnostic value of isolated lesions of the small duct system will be still more insignificant, especially in aged patients.

Reports concerning the appearance of the main duct are controversial. According to Schaffner ${ }^{11}$ and Stole $^{12}$ the main duct of the normal pancreas is free of dilatations or stenosis. In contrast, Anacker ${ }^{13}$ and Classen ${ }^{14}$ assume slight irregularities of the main duct to be within the normal range. Sarles et $a^{15}$ found incomplete stenosis of the main duct in $6.6 \%$ of normal controls. Earlier studies of our group 9 revealed distinct luminal deviations of the main duct in more than $25 \%$ of normal controls, older than 45 years. In the present study, the high incidence of false positive diagnosis of moderate chronic pancreatitis, deriving from the presence of slight alterations of the main duct, confirms this finding. Therefore the criteria of moderate pancratitis in ERCP 'abnormal main duct with or without branch changes ${ }^{10}$ may not be sufficiently specific. The results of our study support the thesis of Reuben $e t$ $a l^{16}$ that endoscopic pancreatography provides accurate distinction only when radiographs are interpreted with knowledge of the clinical data.

The significant correlations between ductal epithelial hyperplasia, intralobular fibrosis and perlobular fibrosis, as well as their age-dependency support the hypothesis, presented in a previous study, ${ }^{6}$ that age-dependent pancreatic lesions start with intraductal epithelial proliferation, followed by intralobular and perilobular fibrosis. Two kinds of mechanism may be involved in the development of perilobular fibrosis. On the one hand, the intralobular lesions may produce a perilobular oedema with secondary fibrosis. On the other hand, the intralobular alterations may release lipase, resulting in perilobular fat necrosis, followed by perilobular fibrosis. Statitistical correlation analyses support the second hypothesis. Moreover, an obvious coincidence of partly resorbed fat necrosis and perilobular fibrosis was not infrequently visible in our material (Fig. 4). The significant correlation between ductographical lesions and perilobular fibrosis favours the assumption that perilobular fibrosis plays a key role in the development of ductal lesions in patients without chronic pancreatitis. In contrast, in our study protein plugs have no influence on the development of perilobular fibrosis

Table 2 Evaluation of postmortem ductograms of patients without chronic pancreatitis $(n=69)$

\begin{tabular}{|c|c|c|c|c|c|c|c|c|c|}
\hline \multirow[b]{4}{*}{ Ductographic evaluation } & \multicolumn{9}{|c|}{ Diagnosis of the observer } \\
\hline & & & $C h r$ & pancre & & & & & \\
\hline & \multicolumn{2}{|c|}{ Normal } & \multicolumn{2}{|c|}{ Grade 1} & \multicolumn{2}{|c|}{ Grade 2} & \multicolumn{2}{|c|}{ Grade 3} & \multirow{2}{*}{$\begin{array}{l}\text { Mean grading } \\
\text { of all } \\
\text { ductograms } \\
\bar{x} \pm s\end{array}$} \\
\hline & $n$ & $\%$ & $n$ & $\%$ & $n$ & $\%$ & $n$ & $\%$ & \\
\hline Observer no 1 & 9 & 13 & 21 & 30 & 33 & 48 & 6 & 9 & $1 \cdot 52 \pm 0.83$ \\
\hline Observer no 2 & 6 & 9 & 30 & 43 & 28 & 41 & 5 & 7 & $1.43 \pm 0.78$ \\
\hline Observer no 3 & 8 & 12 & 27 & 39 & 30 & 43 & 4 & 6 & $1.45 \pm 0.76$ \\
\hline Observer no 4 & 40 & 58 & 25 & 36 & 3 & 4 & 1 & 2 & $0.52 \pm 0.66$ \\
\hline Observer no 5 & 1 & 2 & 27 & 39 & 23 & 33 & 18 & 26 & $1 \cdot 87 \pm 0 \cdot 84$ \\
\hline Observer no 6 & 15 & 22 & 24 & 35 & 21 & 30 & 9 & 13 & $1 \cdot 38 \pm 0.97$ \\
\hline Overall & & $19 \cdot 1$ & & $37 \cdot 2$ & & $33 \cdot 3$ & & $10 \cdot 4$ & \\
\hline
\end{tabular}

Observer no 4 significantly $(\mathrm{p}<0 \cdot 001)$ reduced versus no $1,2,3,5,6$.

Observer no 5 significantly increased versus no $1(\mathrm{p}<0.05)$, no $2,3,6(\mathrm{p}<0.01)$ and no $4(\mathrm{p}<0.001)$. 
Table 3 Incorrect evaluated ductograms by the observers in 69 patients without chronic pancreatitis in postmortem ductograms

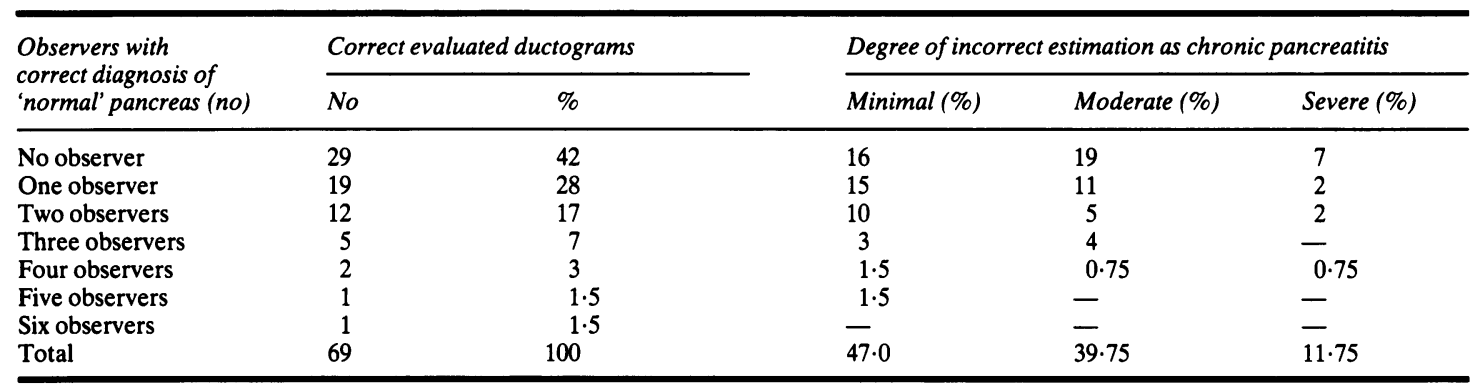

Table 4 Histological evaluation of 69 pancreata without chronic pancreatitis

\begin{tabular}{|c|c|c|c|c|c|c|c|c|c|c|}
\hline \multirow{3}{*}{$\begin{array}{l}\text { Histological } \\
\text { alteration }\end{array}$} & \multicolumn{10}{|c|}{ Grading of alteration } \\
\hline & \multicolumn{2}{|l|}{ No } & \multicolumn{2}{|c|}{ Slight } & \multicolumn{2}{|c|}{ Moderate } & \multicolumn{2}{|c|}{ Severe } & \multicolumn{2}{|c|}{ Alterations (no) } \\
\hline & $n$ & $\%$ & $n$ & $\%$ & $n$ & $\%$ & $n$ & $\%$ & $n$ & $\%$ \\
\hline Hyperplasia of ductal epithelium* & 5 & $7 \cdot 3$ & 40 & $58 \cdot 0$ & 15 & $21 \cdot 7$ & 9 & $13 \cdot 0$ & 64 & $92 \cdot 7$ \\
\hline Periductal fibrosis $\dagger$ & 19 & $27 \cdot 5$ & 33 & $47 \cdot 8$ & 11 & $16 \cdot 0$ & 6 & 8.7 & 50 & $72 \cdot 5$ \\
\hline Intralobular fibrosis $\ddagger$ & 8 & $11 \cdot 6$ & 46 & $66 \cdot 7$ & 9 & $13 \cdot 0$ & 6 & $8 \cdot 7$ & 61 & $88 \cdot 4$ \\
\hline Perilobular fibrosis§ & 9 & $13 \cdot 0$ & 30 & $43 \cdot 5$ & 19 & $27 \cdot 5$ & 11 & $16 \cdot 0$ & 60 & $87 \cdot 0$ \\
\hline Protein plugs $\|$ & 42 & $60 \cdot 9$ & 22 & 31.9 & 4 & $5 \cdot 8$ & 1 & 1.4 & 27 & 39.1 \\
\hline Fat necrosis & 38 & $55 \cdot 1$ & 27 & $39 \cdot 1$ & 4 & $5 \cdot 8$ & 0 & 0 & 31 & 44.9 \\
\hline
\end{tabular}

* Significantly correlated to perilobular fibrosis $p<0.01)$, intralobular fibrosis $(p<0.001)$ and fat necrosis $(p<0.65)$.

+ Significantly correlated to intralobular fibrosis $(p<0.01)$.

‡ Significantly correlated to epithelial hyperplasia $(p<0.001)$ and perilobular fibrosis $(p<0.05)$.

$\S$ Significantly correlated to epithelial hyperplasia $(p<0.01)$, intralobular fibrosis $(p<0.05)$ and fat necrosis $(p<0.05)$.

$\|$ No significant correlation at the $5 \%$ level.

I Significantly correlated to epithelial hyperplasia $(p<0.05)$ and perilobular fibrosis $(p<0.05)$.

Table 5 Relationships between ductal alterations and histology in 69 patients without chronic pancreatitis

\begin{tabular}{|c|c|c|c|c|c|c|c|c|c|c|c|c|}
\hline \multirow[b]{3}{*}{$\begin{array}{l}\text { Histological } \\
\text { lesion }\end{array}$} & \multicolumn{12}{|c|}{ Degree of ductal alteration } \\
\hline & \multicolumn{4}{|c|}{$\begin{array}{l}\text { Normal } \\
\text { Age: } 49 \cdot 9 \pm 22 \cdot 8 \text { years* } \\
n=10\end{array}$} & \multicolumn{4}{|c|}{$\begin{array}{l}\text { Borderline } \\
\text { Age: } 64 \cdot 1 \pm 9.5 \text { years* } \\
n=32\end{array}$} & \multicolumn{4}{|c|}{$\begin{array}{l}\text { Abnormal } \\
\text { Age: } 63 \cdot 1 \pm 17 \cdot 9 \text { years* } \\
n=27\end{array}$} \\
\hline & $\begin{array}{l}\text { No } \\
n\end{array}$ & $\begin{array}{l}\text { Slight } \\
n\end{array}$ & $\begin{array}{l}\text { Moderate } \\
n\end{array}$ & $\begin{array}{l}\text { Severe } \\
n\end{array}$ & $\begin{array}{l}\text { No } \\
n\end{array}$ & $\begin{array}{l}\text { Slight } \\
n\end{array}$ & $\begin{array}{l}\text { Moderate } \\
n\end{array}$ & $\begin{array}{l}\text { Severe } \\
n\end{array}$ & $\begin{array}{l}\text { No } \\
n\end{array}$ & $\begin{array}{l}\text { Slight } \\
n\end{array}$ & $\begin{array}{l}\text { Moderate } \\
n\end{array}$ & $\begin{array}{l}\text { Severe } \\
n\end{array}$ \\
\hline Ductal epithelial hyperplasia & 2 & 6 & 0 & 2 & 1 & 20 & 7 & 4 & 2 & 14 & 8 & 3 \\
\hline Periductal fibrosis & 4 & 1 & 3 & 2 & 8 & 17 & 5 & 2 & 7 & 15 & 3 & 2 \\
\hline Intralobular fibrosis & 1 & 6 & 2 & 1 & 4 & 21 & 4 & 3 & 3 & 19 & 3 & $\overline{2}$ \\
\hline Perilobular fibrosis $\dagger$ & 3 & 5 & 0 & 2 & 6 & 14 & 9 & 3 & 0 & 11 & 10 & 6 \\
\hline Intraductal protein plugs & 8 & 2 & 0 & 0 & 20 & 11 & 1 & 0 & 14 & 9 & 3 & 1 \\
\hline Fat necrosis & 7 & 3 & 0 & 0 & 19 & 11 & 2 & 0 & 12 & 13 & 2 & 0 \\
\hline
\end{tabular}

* Significant correlation $(p<0.05)$ to the degree of ductal alteration in the mean values of rating evaluations of the six observers.

+ Significant correlation $(\mathrm{p}<0.01)$ to the degree of ductal alteration in the mean values of rating evaluations of the six observers. 
and ductal lesions. Rather, such protein plugs are produced by ductal stenosis with retention of pancreatic juice. ${ }^{6}$ Ductal lesions in chronic pancreatitis are mainly produced by perilobular fibrosis. ${ }^{12} 17$ As shown by the present study, an identical mechanism may produce ductal lesions in the aging pancreas. This identical formal pathogenesis may also explain the identical pattern of minimal chronic pancreatitis and age-dependent ductal lesions in pancreatic ductograms.

\section{References}

1 McCune WS, Shorb PE, Moscovitz H. Endoscopic cannulation of the ampulla of Vater: a preliminary report. Ann Surg 1968; 167: 752-6.

2 Howard JM, Nedwich A. Correlation of the histologic observations and operative findings in patients with chronic pancreatitis. Surg Gynecol Obstet 1971; 132: 387-95.

3 Kasugai T, Kuno N, Kizu M, Kobayashi S, Hattori K. Endoscopic pancreatocholangiography. II. The pathological endoscopic pancreatocholangiogram Gastroenterology 1972; 63: 227-34.

4 Tympner F, Rösch W, Lutz H, Koch H. Diagnostische Methoden bei der chronischen Pankreatitis. Stellenwert von endoskopisch retrograder Pankreatikographie, volumenverlustkorrigiertem SekretinPankreozymin-Test und Sonographie Dtsch Med Wochenschr 1978; 103: 805.

5 Rösch W. ERCP bei Pankreatitis. In: Demling L, Koch H, Rösch W eds. Endoskopisch-retrograde CholangioPakreatikographie. Schattauer: Stuttgart, 1979: 169-82.

6 Schmitz-Moormann P, Hein J. Altersveränderungen des Pankreasgangsystems und ihre Rückwirkungen auf das Parenchym. Virchows Arch A [Path Anat] 1976; 371: $145-52$.
7 Schmitz-Moormann P, Hein J, Ihm P. Morphometrische Untersuchungen am Gangsystem des menschlichen Pankreas. Anat Anz 1977; 141: 507-11.

8 Schmitz-Moorman P, Otte ChA, Ihm P, Schmidt G. Vergleichende röntgenologische und morphologische Untersuchungen am menschlichen Pankreas. 3. Morphometrische Untersuchungen am Ductus pancreaticus major. Z Gastroenterol 1979; 17: 256-63.

9 Schmitz-Moormann P, Riedel R, Ihm P. Morphometrische Untersuchungen der Kaliberschwankungen am normalen Ductus pancreaticus major. Z Gastroenterol 1981; 19: 299-306.

10 Sarner M, Cotton P. Classification of pancreatitis. International workshop Cambridge, 23-25 March 1983. Gut 1984; 25: 756-9.

11 Schaffner, O. Das normale Pankreatogramm. In: Demling L, Koch H, Rösch W, eds. Endoskopischretrograde Cholangio-Pakreatikographie. Schattauer: Stuttgart, New York, 1979: 129-33.

12 Stolte M. Pankreatographie und Pathomorphologie der Bauchspeicheldrüse. In: Demling $\mathrm{H}$, Koch W, Rösch $\mathrm{S}$, eds. Endoskopisch-retrograde Cholangio-Pankreatikographie. Schattauer: Stuggart, New York, 1979: 135-67.

13 Anacker H. Die pathologischen Veränderungen des Pankreasgangsystems im Röntgenbild. Röfo 1962; 96: 455-69.

14 Classen M, Hellwig H, Rösch W. Anatomy of the pancreatic duct. A duodenoscopic-radiological study. Endoskopy 1973; 5: 14-7.

15 Sarles H, Sahel J, Staub JL, Bourry J, Laugier R. Chronic pancreatitis. In: Howat, HT, Sarles H, eds. The exocrine pancreas. Saunders: London, Philadelphia, Toronto, 1979: 402-39.

16 Reuben $\mathrm{A}$, Johnson $\mathrm{AL}$, Cotton $\mathrm{PB}$. Is pancreatic interpretation reliable? A study of observer variation and error. Br J Radiology 1978; 51: 956-62.

17 Becker V. Bauchspeicheldrüse (Inselapparat ausgenommen). In: Von Doerr, Seifert, Uehlinger, eds. Spezielle pathologische Anatomie, Band 6. Berlin: Springer Verlag, 1973. 